\title{
APOTHECIAL ANATOMY OF SOME PARMELIA SPECIES OF NAMOBUDHA, KAVREPALANCHOWK DISTRICT, CENTRAL NEPAL
}

\author{
K.B. Thapa and S. Rajbhandary
}

\section{ABSTRACT}

The knowledge of lichen in Nepal was for the first type introduced by Wallich's collection done during 1820-21. The collection was mainly done from the eastern and central regions of the country. Lichens are found across all climatic regions of Nepal. They are characterized by the form in which they grow as they can grow on almost any substrate. They are usually identified by its morphological characters, anatomy and colour test in order to separate genera as well as species. Now apothecial ontogeny and structural character is taken to recognise a family, genera and species. Altogether 31 species of different apothecial foliose and fruticose lichens were collected. Among them, 12 species of Parmelia were collected belonging to the family Parmeliaceace. This paper gives the difference of apothecial anatomy of five species of the genus Parmelia collected from Namobudha, Kavrepalanchok district of central Nepal, which has helped in the identification of the species.

Key words: Parmelia, lichen, foliose, fruticose, ascospores

\section{INTRODUCTION}

The lichens are large groups of flowerless plants called 'Rock Moss' in English and 'Jhyaoo' in Nepali (meaning useless things) or 'Tare' (star like). They are unique organisms due to their peculiar duel or composite nature of the thallus produced by the intimate association of two unrelated components viz: fungi and algae. The word 'Lichen' (Lie, ken) was first coined by great philosopher, Theophrastus (300B.C.) in Greek literature, which signifies a superficial outgrowth on the bark of olive trees (Hale 1974, Hawksworth and Hill 1984, Tibell 1992). French botanist Joseph Pitton de Tournefort (1694) used 'lichen' as a generic name but it was the Italian botanist Pietro Antonio Micheli (1729), who first introduced this taxa into systematic classification system and described about 300 species of lichens in his book 'Nova planterum Genera' (Hawksworth and Hill 1984).

The knowledge of lichen in Nepal was for the first time introduced by Wallich's collection done during 1820-21. The collection was mainly done from the eastern and central regions of the country. Nylander in 1860 published his monumental work on lichen "Synopsis Methodica Lichenum", which included some Nepalese specimens collected by Sir Joseph Dalton Hooker and Thompson. Likewise, Paulson (1925) described 31 lichen taxa from Mt. Everest, Nepal, based on the collections of Sommervella in 1924. Similarly, Asahina (1955) described 62 species of lichen and Abbayes (1958) gave an account of the collection and distribution of Cladonia species from Nepal Himalayas. Both the publications were based on the Nakao's collection, who collected the lichen species from different parts of eastern Nepal during the expedition to the Nepal Himalaya in 1952-53. Awasthi (1957) also reported Nepalese lichen for the first time based on his collection done in the eastern Nepal and reported 38 species in his publication (1960a, b, c). Later, Awasthi (1965) also published a catalogue of the lichens 
of South Asia, which includes Nepalese species. Asahina and Kurokawa (1966) reported 70 species of lichens from Nepal.

Lichenologists estimate about 2,000 lichen species in Nepal (Bhuju et al. 2007). Forty-eight lichen species are reported to be endemic to Nepal (Bhuju et al. 2007). Sharma (1995) identified 471 species from 79 genera and 30 families. Studies on lichens have been carried out mainly in eastern and central Nepal. Lichens from the lowland Terai and Siwalik Hills are much less known, and those of western Nepal remain largely unexplored (Bhuju et al. 2007).

They colonize some of the most inhospitable habitats on earth. They can survive in extremely cold areas such as on high mountains and in regions such as the arctic. They may be virtually the only plant form surviving in some of these areas and can be vitally important sources of food for animals. They are also found throughout less extreme climates, inhabiting just about any solid surface. This can range from rocks on sea shores, to walls, trees and concrete. A few are unattached and blow about freely. They are characterized by the form in which they grow as they can grow on almost any substrate. They are usually identified by its morphological characters, anatomy and colour test in order to separate genera as well as species. Recently apothecial ontogeny and structural character is taken to recognise a family, genera and species. This paper gives you the difference of apothecial anatomy of some species of the genus Parmelia, which has helped in the identification of the species.

\section{MATERIALS AND METHODS}

Namobuddha is a hilly area at the height of $1400 \mathrm{~m}$ above sea level. It is situated at $27^{\circ} 18^{\prime}-27^{\circ}$ $46^{\prime} \mathrm{N}$ latitude and $85^{\circ} 24^{\prime}-85^{\circ} 49^{\prime} \mathrm{E}$ longitude at an altitude of $750-2800 \mathrm{~m}$ covering the area of 1369 sq. $\mathrm{Km}$. It is a small area but is a centre of high level of lichen diversity. Administratively, the area falls under ward no. 9 of Shyampati Simalchaur VDC of Kavrepalanchowk district.

Apothecial lichens species were collected and herbarium was prepared. It was preserved by duly spraying with $0.2 \%$ aqueous solution of $\mathrm{HgCl} 2$ to avoid its rotting and dehydration. The lichen specimens were promptly and carefully identified by observing their morphology, anatomy, colour reaction of the thallus and tentatively with the help of available literature. "A Key to the Microlichens of India, Nepal and Sri Lanka" (Awasthi 1991) and "A Key to the Macrolichens of India, Nepal and Sri Lanka" (Awasthi 1988). The specimens were also studied and compared with the herbarium that was preserved in the Central Department of Botany (TUCH) and National Herbarium Section of Godawari, (KATH) Lalitpur, Nepal.

The most useful fundamental generic character lies in the ascospores. Thomson (1963), Hale (1967), and Culberson (1969) have supported this view. Therefore, in the present study attempt has been made to study the ascospores character of Parmelia species apothecial foliose lichen, which is considered as one of the main character to specify lichen species.

\section{RESULTS AND DISCUSSION}

The lichen in this area seems to prefer the bark and twigs of plants and rocks as their substratum, though they also occur on the variety of other substrate. The Parmelia species is found growing abundantly on the bark of Rhododendron, Quercus, Castanopsis, Schima, Alnus, and Juglan sp. at an altitude from 1500-2500m and in shrubs like Berberis, Spondias, Phyllanthus, Myrica, 
Gaultheria, Myrsine species, etc. provide a good substratum for the growth of this species.

Around 31 species of different apothecial foliose and fruticose lichens were collected. Among them, 12 species of Parmelia was collected belonging to the family Parmeliaceace (Table 1). For laboratory identification, the effort was succeeded only by morphology and anatomy (Awasthi 1984) in colour-tests and comparative study of the herbarium which are preserved in the Central Department of Botany. Colour-test done, have real diagnostic value in the separation of genera as well as species and this view is supported by Culberson (1969).

Table 1. List of Parmelia species collected from Namobuddha.

\begin{tabular}{|l|l|l|}
\hline SN & Collection No. & Species names \\
\hline 1. & $002 \mathrm{SK}$ & Parmelia caperata (L.) Ach. \\
\hline 2. & $003 \mathrm{SK}^{*}$ & Parmelia cirrhata Fr. \\
\hline 3. & $004 \mathrm{SK}$ & Parmelia cetrata Ach. \\
\hline 4. & $005 \mathrm{SK}$ & Parmelia exsecta Tayl. \\
\hline 5. & $006 \mathrm{SK}^{*}$ & Parmelia flexilis Kurok. \\
\hline 6. & $007 \mathrm{SK}$ & Parmelia meizospora (Nyl.) Nyl. \\
\hline 7. & $008 \mathrm{SK}^{*}$ & Parmelia nepalensis Tayl. \\
\hline 8. & $009 \mathrm{SK}^{*}$ & Parmelia nilgherrensis Nyl. \\
\hline 9. & $0010 \mathrm{SK}{ }^{*}$ & Parmelia reticulata Tayl. \\
\hline 10. & $0011 \mathrm{SK}^{*}$ & Parmelia rhytidodes Hale \\
\hline 11. & $0012 \mathrm{SK}^{*}$ & Parmelia tinctorum Nyl. \\
\hline 12. & $0013 \mathrm{SK}$ & Parmelia wallichiana Tayl. \\
\hline
\end{tabular}

* Species in which apothecial anatomical study was done.

In the present study, all the 5 species studied have been based on the classification proposed by Poelt (1973). According to his classification, the species belongs to the Class-Ascolichens and Order- Lecanorales and Parmeliaceace family and genera Parmelia. All species are with fruiting body, the apothecia apothecia containing unitunicate asci regularly arranged in a hymenium with free unbranched paraphyses.

\section{Key to the species of Parmelia}

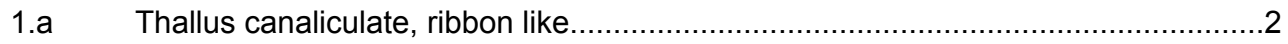

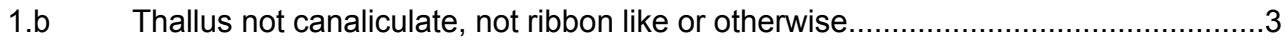

2.a Lower surface uniformly rhizinate, rhizinae dense short, marginal cillia simple or bra nched. P. nepalensis Tayl. 
2.c All or most of the rhizinae dichotomously branched, Medulla $\mathrm{C}^{+}, \mathrm{KC}^{-}$

P. flexilis Kurok.

3.a Maculae reticulate and cracked, rhizinae branched. P. reticulata Tayl.

3.b Upper surface heavily rugose, margin of lobes ciliated. P. rhytidodes Fr.

Parmelia cirrhata Fr. (Syn. Everniastrum cirrhatum (Fr.) Hale).

Syst. Orb. Veget. 1:383. 1825. Zahlbr. Cat lich. Univ. 6:59. 1930. Awasthi, Biol. Mem. 1 (1 \& 2): 168.1976.

Thallus foliose, corticolous, lignicolous, ashy gray to gray, suberect to pendulous, lobes rotund to sub-rotund, margin cilliate, cilia simple to branched up to $2 \mathrm{~mm}$ length, loosely adnate to substratum 5-9 cm in size, laciniate, laciniae 2-6 $\mathrm{mm}$ wide, dichotomously branched with tappering apex, absent of isidia, pustules and soredia, upper surface smooth, rugose, pycnidiate, paraplectenchymatous, corticated on both surface, heteromerous, photobiont green alga belonging to Trebouxia, lower surface lacking rhizinae or with spores, irregularly scattered long rhizinae.

Thallus 160-270 $\mu \mathrm{m}$ thick, upper cortex 18-27 $\mu \mathrm{m}$ thick, algal layer 18-36 $\mu \mathrm{m}$ thick, medulla 103-200 $\mu \mathrm{m}$ thick, lower cortex 18-27 $\mu \mathrm{m}$ thick.

Apothecia marginal to laminal, lecanorine, 2-7 $\mathrm{mm}$ in diameter. Stipitate brown, sessile to shortly stalked, plane to concave, imperforate, epithecium light brown, 18-21 $\mu \mathrm{m}$ thick, hymenium hyaline, 108-117 $\mu \mathrm{m}$ high, asci 8-spored, asci cylindrical, $66.65 \times 24.99 \mu \mathrm{m}$ in size, spores simple, hyaline, oval to ellipsoid, $20.83 \times 8.33 \mu \mathrm{m}$ in size, paraphyses $54.15 \times 8.33 \mu \mathrm{m}$ in size.

Habitat: MosIty corticolous, common on the bark of Quercus, castanopsis, Alnus, and Berberis species.

Specimens examined: Namobuddha 1460m, 11/1/1998, K.B. Thapa \& S. Rajbhandary 003SK (TUCH)

Host: Quercus lanuginosa.

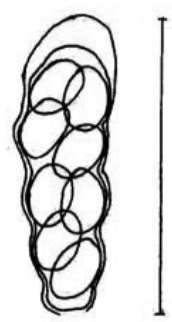

(a)

$66.65 \times 24.99 \mu \mathrm{m}$

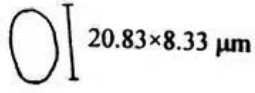

(b)

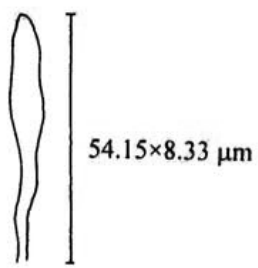

(c)

rigure 1. rarmelia cirrhata Fr. (a) Ascus and ascospores (x 200);

(b) ascospore (x 200); (c) paraphyses. 
Parmelia flexilis Kurok. (syn. Hypotrachyna flexilis (Kurok.) Hale).

In Hara, The Flora of Eastern Himalaya P. 607, 1966. Awasthi, Biol. Mem. 1 (1 \& 2):174, 1976. Thallus foliose, corticolous, ashy gray to whitish gray, irregularly sinuate, lobes irregular and 2-5 mm wide, margin eciliate, crenate, closely adnate to the substratum, 2-6 cm in diameter, isidia and soredia absent, upper surface smooth, lower surface pale to blackish, black rhizinae up to margin, rhizinae dichotomously branched.

Thallus 162-225 $\mu \mathrm{m}$ thick, heteromerous, upper cortex 18-27 $\mu \mathrm{m}$ thick, algal layer 27-36 $\mu \mathrm{m}$ thick, medulla 90-135 $\mu \mathrm{m}$ thick, lower cortex 18-27 $\mu \mathrm{m}$ thick.

Apothecia common and numerious, laminal, sessile, 2-5 cm in diameter, margin distinct, brown coloured, plane to concave, adnate, epithecium light brown, 12-21 $\mu \mathrm{m}$ thick, hymenium colourless, 67-32 $\mu \mathrm{m}$ high, asci 8-spored, asci clavate, $74.98 \times 33.32 \mu \mathrm{m}$ in size, spores hyaline and oval to ellipsoid, $16.66 \times 8.33 \mu \mathrm{m}$ in size, paraphyses $66.49 \times 6.24 \mu \mathrm{m}$ in size.

Habitat: Corticolous, common on the bark and twigs of shrubs and trees e.g. Juglan, Spondias, Phyllanthus, and Myrica species.

Specimens examined: Namobuddha 1820m., 29/2/1998, K.B. Thapa \& S. Rajbhandary 006SK (TUCH)

Host: Phyllanthus parvifolius.

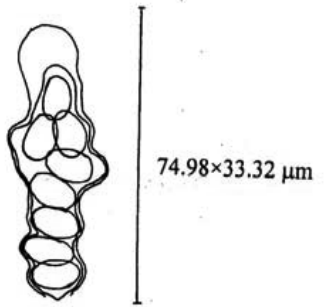

(a)

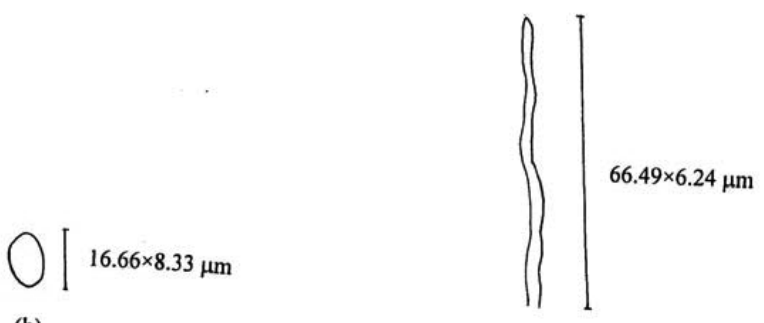

(c)

Figure 2. Parmelia flexilis Kurok. (a) Ascus and ascospores (x 200); (b) ascospore (x 200); (c) paraphyses.

Parmelia nepalensis Tayl. (Syn. Everniastrum nepalense (Tayl.) Hale).

London Journ. Bot 6:172. 1847. Zahlbr. Cat. Lich. Univ. 6:59. 1930. Awasthi, Biol. Mem. 1 (1 \& 2): 133. 1976.

Thallus foliose, corticolous, gray to dark gray, sub-erect to pendulous $4-9 \mathrm{~cm}$ in diameter, laciniate, lobate, laciniae 2-5 $\mathrm{mm}$ wide, elongated, dichotomously branched with tapering apex, margin ciliate, cilia simple to branched, loosely adnate to substratum, isidia and soredia absent, upper surface smooth, convex, lower surface black, canaliculate, uniformly rhizinate, rhizinae short, simple, squarrosely branched to dichotomously branched.

Thallus 200-250 $\mu \mathrm{m}$ thick, upper cortex paraplectenchymatous, 18-27 $\mu \mathrm{m}$ thick, algal layer 18-36 
$\mu \mathrm{m}$ thick, medulla white, $145-155 \mu \mathrm{m}$ thick, lower cortex paraplectenchymatous, $18-27 \mu \mathrm{m}$ thick. Apothecia common, laminal, sessile to sub-stipitate 1-7 mm in diameter, margin distinct, entire to cracked, lobulate, disk brown, concave, epithecium light brown 8-12 $\mu \mathrm{m}$ thick, hymenium colourless, $72-90 \mu \mathrm{m}$ high, asci 8-spored, cylindrical to clavate, $62.45 \times 20.83 \mu \mathrm{m}$ in size, spores hyaline, simple to ellipsoid, $16.66 \times 8.33 \mu \mathrm{m}$ in size, paraphyses $54.15 \times 2.08 \mu \mathrm{m}$ in size.

Habitat: Corticolous common on bark and twigs of trees and bushes e.g. Rhododendron, Berberis, and Myrsine species in open and dry cool place.

Specimens examined: Namobuddha 1690 m., 11/3/1998, K.B. Thapa \& S. Rajbhandary 008SK (TUCH)

Host: Myrsine semiserrata.

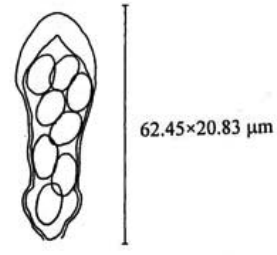

(a)

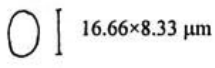

(b)

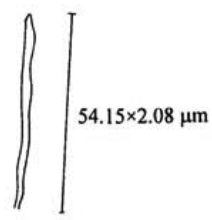

(c)

Figure 3. Parmelia nepalensis Tayl. (a) Ascus and ascospores ( $x$ 200); (b) ascospore ( $x$ 200); (c) paraphyses.

Parmelia reticulata Tayl. (Syn. Parmotrema reticulatum (Tayl.) Choisy).

In Mack, Fl. Hibern 2:148, 1836. Zahlbr. Cat. lich. Univ. 6:192, 1930. Awasthi, Biol. Mem. 1 (1 \& 2) : 217. 1976.

Thallus foliose, corticolous or saxicolous, pale to dark gray, $3.9 \mathrm{~cm}$ in size, lobes rotund, imbricate $5-15 \mathrm{~mm}$ wide, margin ascending, crenate, dentate to dichotomoulsy lobed with finger like lacinules, ciliate, cilia sparse and black, 2-3 mm long, loosely adnate to the substratum, non-isidiate but sorediate, upper surface dense, reticulately cracked lower surface black, densely black rhizinate, rhizinae simple to squarrosely branched.

Apothecia common, laminal, short-stalked, 2-9 mm in diameter, margin entire, brown, concave, imperforate, amphithecium densely sorediate, epithecium light brown, 9-12 $\mu \mathrm{m}$ thick, hymenium colourless, $108-126 \mu \mathrm{m}$ high, asci-8-spored, asci ellipsoid, $58.33 \times 20.83 \mu \mathrm{m}$ in size, spores simple, hyaline, oval to ellipsoid, $12.49 \times 8.33 \mu \mathrm{m}$ in size, paraphyses $54.15 \times 8.33 \mu \mathrm{m}$ in size.

Habitat: Corticolous, some times saxicolous, common on bark and twigs of trees and shrubs. Myrica, Rhododendron, Berberis, and Gaultheria species.

Specimens Examined: Namobuddha 1500 m, 11/1/1998, K.B. Thapa \& S. Rajbhandary 0010SK (TUCH)

Host: Berberis aristata. 


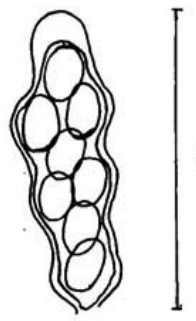

(a)
$58.33 \times 20.83 \mu \mathrm{m}$

$$
O[12.49 \times 8.33 \mu \mathrm{m}
$$

(b)

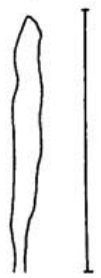

$54.15 \times 8.33 \mu \mathrm{m}$

(c)

Figure 4. Parmelia reticulata Tayl. (a) Ascus and ascospores (x 200);

(b) ascospore (x 200); (c) paraphyses.

Parmelia rhytidodes Hale. (Syn. Parmelina rhytidodes Hale).

Smithson contr. Bot. 33:43. 1976.

Thallus foliose, corticolous, pale to ashy gray, $7-13 \mathrm{~cm}$ in diameter, lobated, $2-3 \mathrm{~cm}$ in dia, crenate, ciliate, cilia sparse, $0.3 \mathrm{~mm}$ long, closely adnate to substratum, non-isidiate but sorediate, upper surface heavily rugose, lower surface black with dense rhizinae, rhizinae $10-15 \mathrm{~mm}$ long. Apothecia common, 2-4 mm in diameter, margin entire, brown, asci 8-spored, ascus clavate, $74.49 \times 24.99 \mu \mathrm{m}$ in size, spores simple and hyaline, spores $12.49 \times 10.41 \mu \mathrm{m}$ in size, paraphyses $37.49 \times 2.08 \mu \mathrm{m}$ in size.

Habitat: Corticolous, common in bark and twigs of trees: Rhododendron, Quercus, Castanopsis, and Schima species.

Specimens Examined: Namobuddha 1540 m, 11/1/1998, K.B. Thapa \& S. Rajbhandary 0011SK (TUCH)

Host: Castanopsis indica.

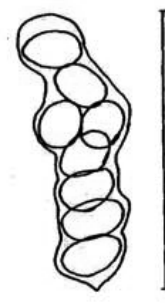

(a)
$74.49 \times 24.99 \mu \mathrm{m}$

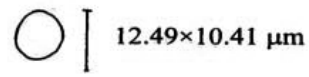

(b)

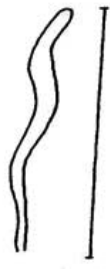

$37.49 \times 2.08 \mu \mathrm{m}$

(c)

Figure 5. Parmelia rhytidodes Hale. (a) Ascus and ascospores (x 200);

(b) ascospore (x 200); (c) paraphyses. 
In the present study, elevation distribution pattern of lichens shows total depends on the topography. Parmelia cirrhata Fr. is collected from the lowest elevation $(1460 \mathrm{~m})$ and Parmelia flexilis (Müll:Arg.) Awas from highest elevation (1820m). While other species reveal the altitudinal preference in between $1460 \mathrm{~m}-1820 \mathrm{~m}$.

Apothecial ontogeny and structural character is taken to recognise a family. The groundwork of this study for 5 species with different apothecia possesses primary characters-sessile to short stalked, disc plane to concave, laminal and lecanorine. Dughi (1954), have also confirmed the presence of lecanorine type of apothecia in the family Parmeliaceae and Usneaceae, which supports the results.

In all the five different Parmelia species eight ascospores are generally observed within each ascus and indicates no variation in number of ascospores, this results supports the view of Santesson (1952), who have described the number of spores, most commonly as eight. But the ascospores occasionally differ greatly in size, probably due to the shape and size of the ascus, largest spore size $(20.83 \times 8.33 \mathrm{~mm})$ was in Parmelia cirrhata Fr. and small size $(12.49 \times 8.33$ $\mu \mathrm{m})$ was found in Parmelia nepalensis Tayl. They are predominantly oval to ellipsoid in shape and usually quite uniform if the length-wide index is low. Spores are colourless in all the species which supports the view of Hale (1974).

Going through the observation obtained from the apothecial anatomy of these lichens, it can be concluded that different species of lichen can also be identified with the help of the measurement of ascus, ascospores and paraphyses, as the ascospores even though same in number occasionally differ greatly in size from species to species, probably due to difference in the shape and size of the ascus of individual species.

\section{ACKNOWLEDGEMENTS}

The authors like to thank the teachers of Central Department of Botany, Tribhuvan University, Kirtipur, Kathmandu, Nepal for their help and valuable suggestions. Our sincere acknowledgement also goes to the local people of the study area for their kind information and suggestion about the study area. A special thanks to our friends for helping in the field visit.

\section{REFERENCES}

Abbayes, H.D.,1958. Resultats des Expeditions Scientifiques Genevoises and Nepal en 1952 et 1954 (Partie Botanique). Candollea, 16:201-209.

Asahina, Y.,1955. Lichens. In Kiraha, H. Fauna and flora of Nepal Himalaya. scientific results of the Japanese expedition of Nepal Himalaya (1952-53), Kyoto Univ., Kyoto, Japan, 1:44-63. Asahina, Y. and S. Kurokawa,1966. Lichens. In Kiraha, H. (ed) The flora of Eastern Nepal Himalaya. Univ. Tokyo, 592-605.

Awasthi, D.D., 1957. On new lichens from the Himalayas. Proc. Indian Acad. Sci., 45:129-139. Awasthi, D.D.,1960a. Contributions to the lichen flora of India and Nepal. I. The genus Physcia (Ach.) Vain. Jour. Indian Bot. Soc., 39(1):1-21.

Awasthi, D.D.,1960b. Contributions to the lichen flora of India and Nepal. II. The genus Anaptychia Körb. Jour. Indian Bot. Soc., 39(3):415-442. 
Awasthi, D.D.,1960c. On a collection of macrolichens by the Indian expedition to Cho-Oyu, east Nepal. Proc. Indian Acad. Sci., 51B(4):169-180.

Awasthi, D.D.,1965. Catalogue of lichens from India, Nepal, Pakistan, and Ceylon. Beihefte zur Nova Hedwigia, Heft 17. Verlag von J. Cramer, Weinheim,137 p.

Awasthi, D.D.,1984. The lichen genera Hypogymnia and Menegazzia from India and Nepal. Kavaka, 12:87-97.

Awasthi, D.D.,1988. A key to the macrolichens of India, Nepal and Sri Lanka. Journ. Hattori Bot., 65:207-302.

Awasthi, D.D.,1991. A Key to the microlichens of India, Nepal and Sri Lanka. Bibliotheca Lichenologica, 40:1-336 + Addendum.

Bhuju, U.K., P.R. Shakya, T.B. Basnet and S. Shrestha, 2007. Nepal biodiversity resource book: Protected areas, Ramsar sites, and world heritage sites. ICIMOD, MOST and GoN.

Culberson, C.F.,1969. Chemical and botanical guide to lichen products. University of North Carolina Press, Chapel Hill.

Hale, M.E.,1967. The biology of lichens. Edward Arnold Ltd, London, pp 1-175.

Hale, M.E., 1974. The biology of lichens. Edward Arnold (Publishers) Ltd., 25 Hill Street, London, pp 1-181 (2nd edition).

Hawksworth, D.L. and D.J. Hill, 1984. The lichen-forming fungi. Blackie and son Ltd. Glasgow, pp 1-158. Micheli, P.A.,1729. Nova Plantarum Genera Juxta Tournefortii methodum disosita. Firenge, 234 p.

Nylander, W.,1860. Synopsis methodica lichenum, Vol. I. 1985-60: 430 Paris.

Paulson, R.,1925. Lichen of Mount Everest. J. Bot. Lond., 63:189-193.

Poelt, J.,1973. Classification. In Ahmadjian, V. and M.E. Hale (eds) The lichens. Academic Press, New York. pp 599-632.

Santesson, R.,1952. Folicolous lichens. I. Symb. Bot. Upsal.,12, I.

Sharma, L.R.,1995. Enumeration of the lichens of Nepal. Verheught, W.J.M. (ed.) Ministry of Forest and Soil Conservation and Department of National Parks and Wildlife Conservation Tech. Pub. No. 31-111.

Thomson, J.W.,1963. Beih. Nova Hedwigia, 7. I.

Tibell, L., 992. Crustose lichens as indicators of forest community in borreal coniferous forests. Nord. J. Bot., 12(4): 427-450.

Tournefort, J.P.,1694. De Elemens de botanique, 3 Vols. Paris.

\section{AUTHOR'S ADDRESS}

\section{Khem B. Thapa and Sangeeta Rajbhandary}

Central Department of Botany,

Tribhuvan University, Kirtipur Nepal

(email: imogine3@gmail.com) 